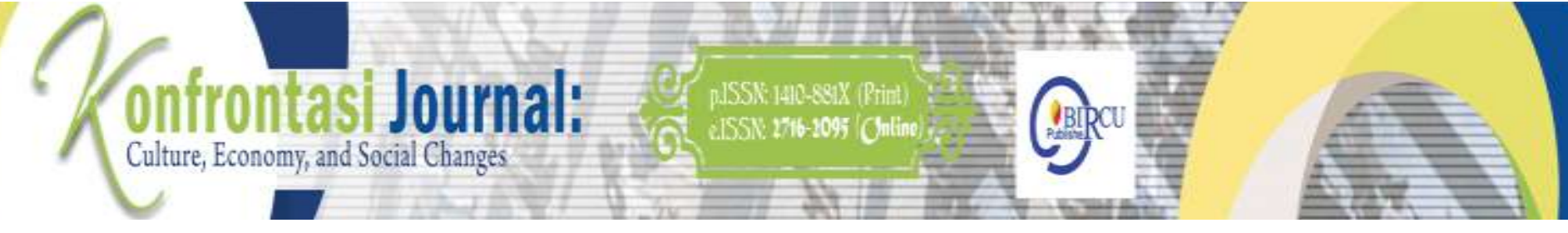

\title{
Coercion or Cost-Decrease: Why Do Firms Pay Influences?
}

\author{
Israel Odion E. Idewele ${ }^{1}$, Peter Eriki' ${ }^{2}$, Murad A. Bein ${ }^{3}$, M. Yoserizal Saragih ${ }^{4}$ \\ ${ }^{1}$ Faculty of Economics and Administrative Sciences, Cyprus International University, Turkey \\ ${ }^{2}$ Department of Banking and Finance, University of Benin, Benin City, Edo State, Nigeria \\ ${ }^{3}$ Department of Accounting and Finance, Cyprus International University, Turkey \\ ${ }^{4}$ Universitas Islam Negeri Sumatera Utara, Medan, Indonesia \\ idewelei@veritas.edu.ng,petereriki@gmail.com, mbein@gmail.com,yosesaragih77@gmail.com
}

\begin{abstract}
It has been observed that Firms Influence Government Authorities by paying Bribe to them. This paper examines how gift is related with the potential for the firm to discover legitimate government authorities. This paper attempts to ascertain why firms pay bribes. More specifically, does it appear that firms are being extorted or is it more likely that they are using bribes as a tool to avoid regulation? In the event that organizations that report more prominent chances to discover government authority pay bribe, at that point this is an indication that rewards originated from coercion in light of the fact that the nearness of such authorities ought not make any difference for firms needing to pay bribe to reduced costs. We find out that influences emerge because of coercion in spite of the fact that result fairly debilitate in the most current study. If corrupt individuals are more likely to enter into environments that allow them to extract bribes, then honest could be endogenous and driven by the prevalence and magnitude of bribery.
\end{abstract}

Keywords coercion; corruption; extortion, bribery, government authority

\section{Introduction}

Mauro (1995) and other experimental investigations find that debasement brings down monetary development or investment. Firms are never again exploited people yet could considerably proffer the pay off as to stay away from over the top guideline. Government officials are increasingly detached in this situation as the genuine hindrances to development become the administrative deterrents firms must dodge. This paper endeavors to recognize the two and determine why firms pay bribe. All the more explicitly, does it give the idea that organizations are being coerced or is it almost certain that they are utilizing fixes as an instrument to dodge guideline? The observational methodology is to depend on a study question solicited in a few rounds from the reviews from the European Bank of Reconstruction and Development. These are firm dimension studies of for the most part post-socialist nations. This inquiry relates to how frequently a firm can swing to an official to get the right strategy if another official is acting inappropriately. The remainder of the paper is organized as follows. Section II briefly summarizes theoretical models where bribes are either a form of extortion or a way to avoid regulation. Section III describes the data and empirical models. Section IV presents results. A conclusion follows in section $\mathrm{V}$. 


\section{Review of Literature}

Government officials may not unequivocally coerce firms but rather they force such cumbersome guidelines that organizations start rewards in order to lessen their expenses. Banerjee (1997) gives a model. In such a setting, the administrative condition is endogenous and turns into a roundabout method to blackmail firms. One model concerns whether advertise rivalry diminishes or increases defilement. Rose-Ackerman (1978) models corrup-tion as blackmail. Market rivalry at that point lessens leases thus brings down the sum that can be coerced by degenerate officials. Ecstasy and Di Tella (1997) and Ades and Di Tella (1999) grow more nuanced models in that degenerate officials could endeavor to augment what they can blackmail by driving less efficient firms bankrupt. Then again, Straub (2009) and Alexeev and Song (2013) create models where firms can influence officials to diminish costs thus gain an upper hand over opponents. Sequeira and Djankov (2010) formally analyze how the idea of defilement and, explicitly, regardless of whether it is driven by blackmail or cost decrease matters for how showcase rivalry impacts renumeration. Shleifer (2004) likewise thinks about the two kinds of debasement. Model Ijah Mulyani Sihotang, and, Pipit Putri Hariani MD (2021) state that spending under every friendly security net. Moreover, the investigation likewise assesses the Livelihood Enhancement and Protection (LEP) program which is a significant activity for neediness mitigation under Ehsaas program and found that resource arrangement and abilities trainings are useful in expanding the profit and give manageable job freedoms to helpless families. Noah Echa Attah etal (2021), took a gander at COVID 19 and Increased Security Challenges in Northern Nigeria: Interrogating Armed Banditry in Northwestern Nigeria and saw that the equipped outlaws utilized the COVID 19 lock down strategy to expand assaults on certain networks, along these lines giving a perplexing measurement to provincial banditry in Northwestern Nigeria. This prompted expanded air and land hostile by the Nigerian military against the criminals. Imam Prayogo and Teuku Afriza (2021), state that there are contrasts in discernments between showing bookkeepers, bookkeeping understudies, and bookkeepers on the morals of getting ready fiscal summaries. Their consequences of this investigation by and large show that the degree of instruction and experience can give a bookkeeper a more significant level of comprehension. Along these lines, a bookkeeper who has an adequate degree of training and furthermore has moderately much experience can be said to have a superior moral view of the readiness of budget reports. Waluyo Jati(2021), states that to screen the development rate or development of Non-Performing Loans (NPLs) so as not to disregard the arrangements of Indonesian banks, it is better if PT. Bank Victoria International Tbk should be more cautious in giving credit to forthcoming clients, first PT. Bank Victoria International Tbk should see the capacity of forthcoming clients to reimburse their credits.

\section{Research Methods}

We utilize three versions of the Business Environment and Enterprise Performance (BEEP) overviews from the European Bank for Reconstruction and Development related to the World Bank. The three versions are the 1999, 2002, and 2005 surveys.3 I consider these three studies since their review questions and test are sufficiently comparable in order to utilize normal details and in light of the fact that, in particular, different studies, (for example, the 2009 and 2012 BEEP overviews) need addresses expected to determine 
whether firms have chances to go to different officials for right treatment if a first official acts inappropriately. The absence of such inquiries is additionally why I don't utilize studies from the World Bank that think about a more extensive scope of creating nations.

The ordinal variable originates from the inquiry: "Usually for firms in my line of business to need to pay some unpredictable 'extra installments/blessings' to complete things respect to traditions, charges, licenses, guidelines, administrations, and so on". Reactions take on whole number qualities from 1 (never) to 6 (dependably). The second influence variable, BRIBE_LEV, originates from the accompanying inquiry: "by and large, what percent of all out yearly deals do firms like yours ordinarily pay in unofficial installments/endowments to open authorities". Two inquiries become important with respect to the pertinence of the two factors. To start with, can these measures possibly represent both coercion and cost decrease? Second, do firms' reactions precisely mirror the dimension of debasement? For this first issue, Alexeev and Song (2013) center around the expression "to complete things" in inquiries with respect to pay off and gather that this expression all the more intently relates to cost diminishing defilement. To them, "to complete things" infers slicing through formality. In one case, a firm worried about expensive deferrals could influence an official to move these contributions to the first of the line, accordingly lessening its expenses. Yet, in a second case, assume a traditions official takes steps to "lose" these merchandise except if he gets a fix, an unmistakable instance of coercion. In the two cases, the firm is paying to complete things. It is paying to all the more rapidly get its shipment. The applicable qualification between these two cases in this precedent is whether the firm or the legislature official starts the influence.

The firm is never gotten some information about this qualification among blackmail and cost decrease. All the for the most part, the firm isn't even legitimately inquired as to whether it pays fixes since most respondents would not admit to an illicit demonstration. Rather, the responder is gotten some information about influences paid by "firms like yours". The assumption is that the company's reaction is exceptionally related with its own encounters. The reward factors in Clarke and Xu (2004) and Berg et al. (2012) additionally start from comparable study addresses that don't get some information about its own pay off installments however about its view of the business when all is said in done. By the by, not exclusively should one be worried that respondents answer honestly however that reactions are precise. Obviously, the nearness of mistakes as well as how they emerge are significant for results. On the off chance that any mistakes in reactions are unadulterated clamor, at that point this commotion would debilitate the relationship among renumeration and the correct hand side factors, driving coefficient assessments to zero and proposing that the affiliations are more grounded than announced beneath.

For every one of the three informational indexes, Table 1 indicates rundown measurements for BRIBE and BRIBE_LEV crosswise over three different classifications of HONEST. Legit is an ordinal variable indicating the possibility to go to another official for "right treatment" if a first official conflicts with the standards. The six classifications are constantly (HONEST $=6$ ), typically, much of the time, in some cases, sometimes, or never $($ HONEST $=1)$. For every datum set, firms that can generally or as a rule find legitimate treatment pay less fixes albeit far less difference emerges between the never/sometimes and the occasionally/as often as possible classifications. On the off chance that rewards were constantly started by the firm to lessen costs, at that point one should see no relationship between the pervasiveness of legit authorities and fix installments. Then again, influence installments are as yet positive for the as a rule/dependably gathering. On the off chance that pay off totally originated from blackmail, at that point one would imagine that the commonness and size of rewards. 
Table 1. Bribery broken down by prevalence of "honest" officials.

\begin{tabular}{|c|c|c|c|c|}
\hline Find Honest Official? & Number of firms & Mean & Std. Deviation & Maximum Bribe \\
\hline & & & BRIBE & \\
\hline & & & 2005 BEEP & \\
\hline & & & Survey & \\
\hline Never/Seldom & 3641 & 2.41 & 1.58 & 6 \\
\hline Sometimes/Frequently & 3106 & 2.44 & 1.33 & 6 \\
\hline Usually/Always & 2128 & 1.92 & 1.36 & 6 \\
\hline & & & 2002 BEEP & \\
\hline & & & Survey & \\
\hline Never/Seldom & 2583 & 2.89 & 1.63 & 6 \\
\hline Sometimes/Frequently & 2218 & 2.63 & 1.33 & 6 \\
\hline Usually/Always & 1123 & 2.15 & 1.41 & 6 \\
\hline & & & 1999 BEEP & \\
\hline & & & Survey & \\
\hline Never/Seldom & 1280 & 3.16 & 1.65 & 6 \\
\hline Sometimes/Frequently & 995 & 2.98 & 1.52 & 6 \\
\hline Usually/Always & 812 & 2.09 & 1.44 & 6 \\
\hline & & & BRIBE_LEV & \\
\hline & & & 2005 BEEP & \\
\hline & & & Survey & \\
\hline Never/Seldom & 3553 & 1.14 & 2.59 & 50 \\
\hline Sometimes/Frequently & 3104 & 1.14 & 2.64 & 40 \\
\hline Usually/Always & 1975 & 0.54 & 1.62 & 20 \\
\hline & & & 2002 BEEP & \\
\hline & & & Survey & \\
\hline Never/Seldom & 2514 & 1.86 & 3.60 & 50 \\
\hline Sometimes/Frequently & 2162 & 1.51 & 3.06 & 30 \\
\hline Usually/Always & 1121 & 0.86 & 2.53 & 33 \\
\hline
\end{tabular}

Formally, a firm finds an honest official when it reports being able to obtain the proper treatment from another government official or a supervisor when a first official acts improperly. BRIBE is an ordinal variable taking on values 1 (Never pay bribe)

BRIBE_LEV is measured as percentage of sales. The 1999 BEEP Survey does not provide data for BRIBE_LEV.

Table 2. Summary statistics

\begin{tabular}{|c|c|c|c|c|c|c|}
\hline & \multicolumn{2}{|c|}{2005 Survey } & \multicolumn{2}{|r|}{2002 Survey } & \multicolumn{2}{|r|}{1999 Survey } \\
\hline & Mean & Std. Dev. & Mean & Std. Dev. & Mean & Std. Dev. \\
\hline BRIBE & 2.45 & 1.48 & 2.70 & 1.51 & 2.87 & 1.62 \\
\hline BRIBE_LEV & 1.22 & 2.65 & 1.80 & 3.45 & & \\
\hline HONEST & 2.95 & 1.50 & 2.90 & 1.47 & 3.10 & 1.63 \\
\hline GOV & 8.35 & 26.66 & 13.57 & 32.59 & 20.78 & 40.58 \\
\hline FOREIGN & 8.51 & 25.61 & 11.93 & 29.36 & 12.44 & 33.01 \\
\hline EXPORT & 0.74 & 1.44 & 0.83 & 1.49 & 0.84 & 1.49 \\
\hline TAX & 4.45 & 0.32 & 4.35 & 0.48 & 3.61 & 2.53 \\
\hline SIZE & 3.05 & 1.65 & 2.37 & 1.58 & 3.84 & 1.62 \\
\hline SALESGOV & 1.09 & 1.61 & 0.94 & 1.57 & 1.63 & 1.69 \\
\hline AGE & 2.40 & 0.74 & 2.24 & 0.83 & 2.13 & 0.80 \\
\hline CAPITAL & 0.32 & 0.47 & 0.32 & 0.47 & 0.33 & 0.47 \\
\hline$\#$ of firms & & 6983 & & 4686 & & 2646 \\
\hline
\end{tabular}


TAX (except for 1999), SIZE (except for 2002 and 1999), EXPORT, SALESGOV, and AGE are expressed as natural logarithms. BRIBE_LEV data not available in 1999 BEEP Survey.

TAX in 1999 survey and SIZE in 1999 and 2002 surveys are ordinal variables.

Would be zero for this group. ${ }^{8}$ Of course, these associations are not conditioned upon various other factors that could influence these relationships.

Table 2 reports summary statistics. Bribery is most prevalent in the 1999 survey and least prevalent for the non-post-communist countries. The opportunity to find honest officials is also greatest in this latter group with less difference across the other three samples.

Empirical Model

Consider the following equation:

$$
\text { BRIBE }_{j k i}{ }^{1 / 4} \delta_{i} \text { p } \alpha \text { SALES }_{j k i} p \beta \text { HONEST }_{j k i} p \sigma X_{j k i} p \varepsilon_{j k i} ;(1)
$$

Where $\mathrm{j}$ signifies the firm, $\mathrm{k}$ means the business, and I indicates the nation. BRIBE* is the careful yet in secret level of renumeration. Rather than BRIBE*, firms report a dimension of renumeration given by the ordinal variable, BRIBE, which takes on number qualities from 1 to 6 with higher qualities indicating a more noteworthy pervasiveness of gift. Nation explicit captures meant by $\delta$ i catch countrywide determinants of defilement. Initial, a reaction of "Dependably" about whether a firm can get the right treatment when a first official acts inappropriately does not infer that no deceptive officials exist, just that at any rate one other official gives the right treatment. All the more by and large, this is a significant refinement as the overview gives data in regards to the possibility to look for legitimate treatment, not the level of officials that would give appropriate treatment. Second, the reason of the inquiry is that some first official is acting inappropriately inferring that not all officials are "straightforward". Thusly, as per the reason of the inquiry the firm has the chance to experience a "deceptive" one.

A second shortcoming includes the conceivable endogeneity of legit officials. Maybe legit people are less inclined to self-select into conditions where defilement is uncontrolled while unscrupulous people favor such movement. In the event that genuine, at that point a negative coefficient on HONEST could mirror this plausibility and not really recommend that the nearness of legit officials brings fixes due down to littler open doors for coercion. All things considered different components affecting certain subgroups of firms can't be discounted. In a perfect world, one could discover instruments that are corresponded with the fidelity of government officials yet not generally connected with pay off.

As an option, I consider the Poisson Pseudo-Maximum Likelihood (PPML) estimator from Silva and Tenreyro (2006) which they discover diminishes the level of predisposition, particularly when the example contains countless. As its name infers, the PPML estimator accept that the needy variable pursues a Poisson appropriation where the densest mass point (in my application) is found at zero and after that thickness decreases as the measure of influence installment increases.11 The PPML estimation is connected to a model that contains a similar right hand side factors as given in (1) however is communicated in multiplicative structure.

I likewise consider a negative binomial estimation system which is an option to Poisson particulars when concerns emerge that the information are over dispersed. A Poisson determination expect that the mean of the conveyance rises to the fluctuation (in spite of the fact that the PPML approach just accept the two are corresponding). At last, I utilize a partial relapse technique initially proposed by Papke and Wooldridge (1996) and further considered in Ramalho, Ramalho, and Murteira (2009).12 Bribes as level of offers 
are compelled to lie somewhere in the range of 0 and $100 \%$ thus exist in the unit interim subsequent to changing over rates into decimals. In my applica-tion, just the lower bound is authoritative as the most elevated announced pay off over each of the three study tests sums half of offers. I make FRACBRIBE by separating the reward percen-tage by 100 thus FRACBRIBE takes on qualities among 0 and $1 / 2$ in my example.

\section{Purposes of Bribes}

Results could likewise differ contingent on the sort of administrative hindrances confronting the firm. Maybe a few firms are blackmailed by traditions officials however different firms start fixes to decrease expenses of making good on regulatory expenses. Preference of the studies is that they ask firms to state for what good reason they pay influences. Motivations to pay fixes (which I indicate as "purposes") include: to get licenses and allows (LIC); to manage charges and expense gathering (TAX); when managing traditions/imports (CUSTOMS); when managing (COURTS); and when managing wellbeing and security guidelines (SAFETY). Reactions are ordinal and are given in whole number qualities from 1 to 6 with higher qualities signifying a more noteworthy predominance for gift for that particular reason. These reviews likewise request that organizations portray what obstructions they face in their business activities. A portion of these snags identify with government guidelines and whether the firm sees a particular government deterrent as grave. I think about five deterrents: getting grants/licenses, managing traditions officials, managing charge officials, bargain ing with the legal executive, and managing work guidelines. For each of these, a firm rates the hindrance on a size of one to four where higher qualities indicate more noteworthy impediments. Given these reasons for paying rewards and these deterrents, I think about how results can differ for explicit reason impediment sets.

For instance, consider licenses and let LIC be the needy variable:

\section{LICjki 1/4 $\delta$ i p $\alpha$ SALESjki p $\beta$ HONESTjki p $\sigma$ Xjki p cjki; (2)}

Where again the precise pervasiveness of pay off to get licenses, LIC*, is in secret yet LIC means the watched ordinal variable thus I again utilize an arranged probit approach. I initially think about the whole example. Is the nearness of fair officials related with rewards used to get licenses/grants? I at that point consider just those organizations revealing that acquiring licenses and allows is a significant hindrance as meant by an estimation of ' 3 ' or ' 4 ' on the one to four whole number scale. Probably, these are the organizations that would have the most motivator to pay rewards in order to diminish costs in getting licenses and allows. To the degree that organizations are starting influences to diminish costs then the chance to go to another official for "right treatment" ought not make any difference and the coefficient on HONEST ought to be zero. I pursue a comparative method when examin-ing TAX, CUSTOMS, SAFETY, and COURTS. A shortcoming, in any case, of this methodology is that a similar variable, HONEST, meaning a general capability of finding suitable treatment from officials is being utilized crosswise over explicit purposes.

I recognize two other potential shortcomings of this methodology. Initially, snags could be emphatically related with each other, likewise with the reasons for which they pay influences. In any case, to best recognize differences crosswise over deterrents or purposes in the experimental procedure, one might want zero connection inside each gathering. With no connection, firms confronting high deterrents acquiring licenses, for instance, would not really confront more noteworthy hindrances in regards to traditions. The equivalent would 
hold for the factors signifying for what purposes firms pay rewards. Powerless relationship inside these two arrangements of factors would then make one progressively sure that one effectively unravels these different purposes. Tragically, positive relationships crosswise over obstructions and crosswise over purposes do emerge as Table 3 appears, making it less unmistakable that gauges with respect to HONEST when one considers business licenses, for instance, are really being driven by this deterrent reason mix.

Second, the above dialog presumes that the impediments firms face are administrative ones thus a fix could possibly enable a firm to keep away from the snag and, subsequently, decrease its expenses. Another plausibility is that a firm sees an impediment at whatever point coercion emerges. Provided that this is true, at that point the snag, itself, is the blackmailed pay off thus the pay off and the impediment are not unmistakable, at any rate about how firms are replying in the overview. Notwithstanding, Panel B of Table 3 demonstrates that there is little relationship between's the pervasiveness of legit officials and how firms see the seriousness of different obstructions. The majority of the revealed connections are close to zero, suggesting that the chance or scarcity in that department of finding fair officials isn't related with these sorts of obstructions.

\section{Results and Discussion}

\subsection{Baseline Results}

I initially think about BRIBE as the needy variable and an arranged probit approach. Results are given in Table 4. In every one of the three reviews, the coefficient on HONEST is negative and measurably noteworthy. Firms that report the capacity to go to different officials when a first official acts inappropriately additionally report less cases of pay off. This affiliation proposes that coercion assumes a job in deciding rewards. In the event that organizations were starting influences to diminish costs, at that point probably the nearness of fair officials would be insignificant. The base board of Table 4 demonstrates that these outcomes are powerful to including the non-post-socialist nations accessible from the overviews inside the example.

The correct portion of Table 4 demonstrates the anticipated probabilities for the six potential estimations of BRIBE given that HONEST $=1$ (top number of every cell) or $=6$ (base number of every cell) and given every other variable are set at their mean qualities. Since BRIBE $=1$ (Never) for most firms, the result BRIBE $=1$ assumes the most elevated likelihood paying little mind to whether HONEST equivalents one or six. In any case, expanding HONEST from one to six raises the likelihood of detailing a reaction of "never". These likelihood increments from 0.33 to 0.42 with the 2005 example and the differences for the other two years are significantly more noteworthy. Since few firms answer "continually" with respect to the predominance of renumeration, the anticipated probabilities are low (thus their difference is low also) for both of the thought about estimations of HONEST. By and by, the sizes at the low end for BRIBE do propose that the nearness of genuine officials has a nontrivial bearing upon whether firms report a positive rate of pay off or not. 
Table 3. Correlations across obstacles and bribery purposes

\begin{tabular}{|c|c|c|c|c|c|}
\hline & Taxes & & Customs & Courts & Labor \\
\hline \multicolumn{6}{|c|}{$\begin{array}{l}\text { Panel A: Correlations among Obstacles and } \\
\text { Purposes }\end{array}$} \\
\hline Licenses & $0.61 / 0.41$ & & $0.51 / 0.49$ & $0.52 / 0.38$ & $0.54 / 0.45$ \\
\hline Taxes & & & $0.62 / 0.45$ & $0.58 / 0.37$ & $0.52 / 0.39$ \\
\hline Customs & & & & $0.64 / 0.38$ & $0.52 / 0.37$ \\
\hline Courts & & & & & $0.54 / 0.38$ \\
\hline 2002 & Taxes & & Customs & Courts & Labor \\
\hline Licenses & $0.59 / 0.36$ & & $0.50 / 0.50$ & $0.52 / 0.35$ & $0.55 / 0.42$ \\
\hline Taxes & & & $0.59 / 0.45$ & $0.55 / 0.29$ & $0.49 / 0.29$ \\
\hline Customs & & & & $0.59 / 0.34$ & $0.51 / 0.35$ \\
\hline Courts & & & & & $0.51 / 0.35$ \\
\hline 1999 & Taxes & & Customs & & \\
\hline Licenses & $0.27 / 0.64$ & & $0.35 / 0.58$ & & \\
\hline Taxes & & & $0.30 / 0.56$ & & \\
\hline \multicolumn{6}{|c|}{$\begin{array}{l}\text { Panel B: Correlations of Obstacle with HONEST } \\
\text { Custom }\end{array}$} \\
\hline & Taxes & $\mathrm{s}$ & Licenses & Labor & Courts \\
\hline 2005 & -0.030 & 0.009 & -0.004 & -0.003 & -0.039 \\
\hline 2002 & -0.070 & 0.023 & -0.052 & 0.011 & 0.006 \\
\hline 1999 & -0.149 & -0.115 & -0.125 & NA & NA \\
\hline
\end{tabular}

In panel $\mathrm{A}$, the cells take the form $\mathrm{x} / \mathrm{y}$. The first number, $\mathrm{x}$, of each cell denotes the correlation between the two relevant obstacles. The second number, $y$, denotes the correlation between the two purposes for which firms report bribery. Fewer categories are provided with the 1999 BEEP Survey.

Prior to continuing, I quickly state results for the control factors. Firms that are at any rate to some degree claimed by the administration report less rewards. More seasoned firms report less. As expressed, more established firms may have discovered different approaches to abstain from paying influences, for example, organizing with significant government officials. Those that report a more prominent division of offers to the administration for expense purposes likewise report less fixes. This could emerge in light of the fact that revealing more prominent deals could flag a more elevated amount of trust in government officials by the firm just as an increasingly agreeable connection among business and government. Firms situated in the capital pay more. One probability is that organizations situate in the cash-flow to exploit chances to fix. A second plausibility, notwithstanding, is that administration officials think that its most effortless to blackmail adjacent firms.

Results for the other control factors are not uniform crosswise over reviews. Some proof emerges that outside firms pay less rewards in spite of the fact that this does not hold in the 2005 study. No solid affiliation is found with the span of the firm. In two of the overviews (with the 1999 study as the special case), firms that trade report progressively visit pay off installments, conceivably in light of the fact that sending products through traditions gives another layer of administration where firms could be paying rewards. Another plausibility is that organizations that send out are more productive than generally comparable firms as are more in danger for blackmail.

Table 5 presents outcomes when BRIBE_LEV replaces BRIBE despite the fact that, as expressed, BRIBE_LEV isn't accessible inside the 1999 review. BRIBE_LEV means the dimension of pay off installments as a level of yearly deals thus can more readily address 
the size of reward installments, yet not their recurrence. Given the previously mentioned discourse concerning how to best gauge this determination, Table 5 thinks about a few procedures. Notwithstanding, paying little respect to the estimation system, the coefficient on HONEST is negative and noteworthy at the

Table 4. Coefficient estimates of ordered probit model with BRIBE as dependent variable. row) and $=6$ (bottom)

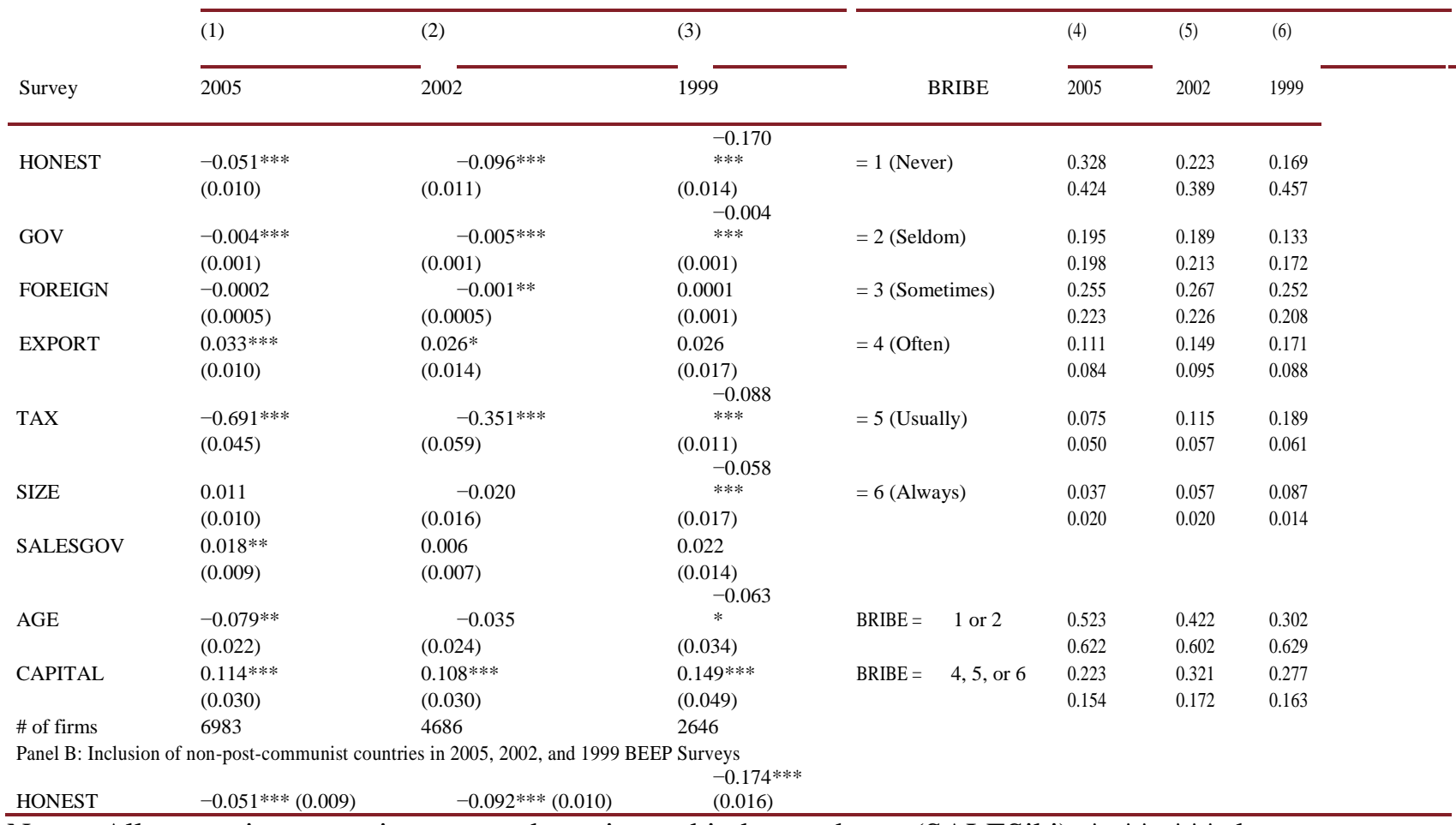

Notes: All regressions contain country dummies and industry shares (SALESjki). *, **, *** denote significance at the 10\%, 5\%, and 1\% level, respectively. Standard errors in parentheses. Specifications in panel B are identical to those in panel A. To compute the predicted probabilities of BRIBE taking on each response, all variables are set at their means except for HONEST which equals one (top number of each cell) or six (bottom number).

Table 5. Coefficients upon HONEST across estimation methodologies using BRIBE_LEV as dependent variable

\begin{tabular}{|c|c|c|c|c|c|}
\hline \multirow[b]{3}{*}{ Survey } & \multicolumn{4}{|c|}{ Coefficient Estimates } & \multirow{2}{*}{$\frac{\text { Magnitudes }}{(4)}$} \\
\hline & (1) & (2) & (3) & & \\
\hline & 2005 & 2002 & 2005 & & 2002 \\
\hline Tobit $(\log )$ & $\begin{array}{l}-0.095^{* * *} \\
(0.014)\end{array}$ & $\begin{array}{l}-0.113 * * * \\
(0.017)\end{array}$ & $-0.095^{* * *}$ & & -0.113 *** \\
\hline Tobit & $\begin{array}{l}-0.343^{* * * *} \\
(0.049)\end{array}$ & $\begin{array}{l}-0.437 * * * \\
(0.073)\end{array}$ & $-0.343 * * *$ & & $-0.437 * * *$ \\
\hline PPML & $\begin{array}{l}-0.113^{* * * *} \\
(0.008)\end{array}$ & $\begin{array}{l}-0.099 * * * \\
(0.019)\end{array}$ & $\begin{array}{l}1.406 * * * \\
0.782 * * *\end{array}$ & & $\begin{array}{l}2.046 * * * \\
1.250 * * *\end{array}$ \\
\hline Fractional & $\begin{array}{l}-0.119 * * * \\
(0.018)\end{array}$ & $\begin{array}{l}-0.098 * * * \\
(0.022)\end{array}$ & $\begin{array}{l}0.014 * * * \\
0.009 * * *\end{array}$ & & $\begin{array}{l}0.020 * * * \\
0.013 * * *\end{array}$ \\
\hline $\begin{array}{l}\text { Negative } \\
\text { Binomial }\end{array}$ & $\begin{array}{l}-0.133^{* * *} \\
(0.019)\end{array}$ & $\begin{array}{l}-0.122 * * * \\
(0.025)\end{array}$ & $\begin{array}{l}1.517 * * * \\
0.778 * * *\end{array}$ & & $\begin{array}{l}2.205 * * * \\
1.199 * * *\end{array}$ \\
\hline \# firms & 6983 & & & 6983 & 4578 \\
\hline
\end{tabular}


Note: $*, * *, * * *$ denote significance at the $10 \%, 5 \%$, and $1 \%$ level, respectively. All specifications use the same controls listed in Table 4 and also include country dummies and industry share variables. The magnitudes for the Tobit specifications are simply the coefficient estimates. The magnitudes for the PPML and Fractional Regression Models are the predicted means given that HONEST $=1$ (top row) and HONEST $=6$ (bottom row). The magnitudes for the negative binomial and PPML specifications are the predicted number of events given that HONEST $=1$ (top row) and HONEST $=6$ (bottom row). BRIBE_LEV not available in 1999 BEEP Survey.

$1 \%$ level for every one of the three studies. Firms that report having the option to go to a legit official for right treatment likewise report lower pay off sums. Sections three and four present sizes when again setting the control factors at their methods. The coefficient appraises on HONEST from the tobit estimations gives the negligible impact of HONEST upon BRIBE_LEV. The announced sizes in sections 3- 4 for the rest of the determinations are the anticipated methods when all factors are set at their methods aside from HONEST. The top line gives the anticipated mean of the reliant variable when HONEST $=1$ (no chance to go to a genuine authority) and the base column does likewise however for HONEST $=6$ (a firm can generally look for right treatment from another authority). As a rule, the anticipated mean when HONEST $=1$ is twice that when HONEST $=6$, proposing that the measure of pay off roughly duplicates when genuine authorities can't be found.

Table 6. Coefficient estimates for HONEST in an ordered probit model.

\begin{tabular}{|c|c|c|c|c|c|}
\hline Purpose/Obstacle & $\begin{array}{c}\text { Licenses and } \\
\text { Permits }\end{array}$ & $\begin{array}{c}\text { Tax } \\
\text { Administration }\end{array}$ & Customs & Courts & $\begin{array}{l}\text { Labor/Safety } \\
\text { Regulations }\end{array}$ \\
\hline \multicolumn{6}{|c|}{ Panel A: Full Sample } \\
\hline \multirow[t]{2}{*}{ BEEP 2005} & $-0.026^{* * *}$ & $-0.025^{* *}$ & -0.017 & 0.004 & $-0.017^{*}$ \\
\hline & $(0.010)$ & $(0.010)$ & $(0.012)$ & $(0.011)$ & $(0.010)$ \\
\hline \multirow[t]{2}{*}{ BEEP 2002} & $-0.097 * * *$ & $-0.074 * * *$ & $-0.054 * * *$ & $-0.048 * * *$ & $-0.064 * * *$ \\
\hline & $(0.011)$ & $(0.011)$ & $(0.004)$ & $(0.016)$ & $\begin{array}{l}(0.012) \\
\text { Not }\end{array}$ \\
\hline \multirow[t]{2}{*}{ BEEP 1999} & $-0.170 * * *$ & $-0.185^{* * *}$ & $-0.161 * * *$ & & Available \\
\hline & $\begin{array}{c}(0.019) \\
\text { Panel B: Sample i }\end{array}$ & $\begin{array}{l}\quad(0.017) \\
\text { es only firms rep }\end{array}$ & $\begin{array}{l}(0.021) \\
\text { ting that the re }\end{array}$ & vant obstacle is & "Moderate" or "Major" \\
\hline \multirow[t]{2}{*}{ BEEP 2005} & -0.015 & -0.016 & -0.029 & -0.006 & 0.029 \\
\hline & $(0.017)$ & $(0.014)$ & $(0.019)$ & $(0.018)$ & $(0.019)$ \\
\hline \multirow[t]{2}{*}{ BEEP 2002} & $-0.137 * * *$ & $-0.086 * * *$ & $-0.083 * * *$ & $-0.092 * * *$ & $-0.088^{* * *}$ \\
\hline & $(0.017)$ & $(0.018)$ & $(0.022)$ & $(0.025)$ & $(0.043)$ \\
\hline & & & & & Not \\
\hline \multirow[t]{2}{*}{ BEEP 1999} & $-0.178 * * *$ & $-0.186^{* * *}$ & $-0.166 * * *$ & & Available \\
\hline & $(0.029)$ & $(0.031)$ & $(0.041)$ & & \\
\hline
\end{tabular}

All specifications contain country dummies and industry shares. They also include the same control variables as listed in Panel A of Table 4. denote significance at the 10\%, 5\%, and $1 \%$ level, respectively. Standard errors in parentheses. For "Licenses and Permits" the dependent variable is an ordered variable denoting how frequently firms pay bribes to acquire licenses. The obstacle refers to the firm's report of how onerous obtaining such licenses/permits are in conducting business. The other categories are analogous.

Firms announcing that the applicable obstruction is "moderate" or "major" are included.13 The coefficient assesses on HONEST are currently significantly more noteworthy in greatness. In these cases, the nearness of genuine authorities brings down the predominance of fixes, notwithstanding for firms that would apparently be bound to pay fixes to decrease costs. The outcomes for firms from the 2005 review are the most differing. Initially, the gauge results in board and are of lower extent than their partners in the different overviews. Second, coefficient gauges likewise decline in size in board B. 
Presently, proof for cost decreasing pay off - at any rate for those organizations revealing burdensome obstructions - is generally solid given that none of the coefficients in board B are critical.

\section{Conclusion}

This paper by and large finds that the chance to go to another administration official when a first official has acted improperly is adversely connected with the prevalence and size of gift. This finding may appear glaringly evident since the nearness of such authorities brings down the fix that any degenerate authority can charge. Be that as it may, the pertinence of such genuine authorities need not be the situation if firms are effectively searching out authorities to pay off to maintain a strategic distance from guidelines. Since some have contended that renumeration "oils the wheels" and have even formalized such practices by displaying gift as a cost-lessening movement attempted by firms, inspecting what sort of pay off is progressively predominant is a significant examination. This current paper's principle decision is that more noteworthy proof recommends renumeration comes from blackmail. In any case, a few admonitions emerge. The first is that we can't gather from the study why a genuine authority probably won't exist. Is it since all authorities are degenerate or is it in light of the fact that the firm must choose the option to collaborate with one specific authority who while giving the taxpayer supported organization can act like a monopolist? Maybe circumventing a degenerate authority is conceivable yet very time

\section{References}

Ades, A., \& Di Tella, R. (1999). Rents, competition, and corruption. American Economic Review, 89, 982-993.

Aidt, T. (2003). Economic analysis of corruption: A survey. Economic Journal, 113, 632652.

Alexeev, M., \& Song, Y. (2013). Corruption and product market competition: An empirical investigation. Journal of Development Economics, 103, 154-166.

Asieudu, E., \& Freeman, J. A. (2009). The effect of corruption on investment growth: Evidence from firms in Latin America, Sub-Saharan Africa, and transition countries. Review of Development Economics, 13, 200-214.

Banerjee, A. V. (1997). A theory of misgovernance. Quarterly Journal of Economics, 112, 1289-1332. Bayar, G. (2011). Causes of corruption: Dynamic panel data analysis of some post-Soviet countries and East Asian countries. Journal of Applied Business Research, 27, 77-86.

Berg, S. V, Liangliang, J, \& Lin, C. (2012). Regulation and corporate corruption: new evidence from the telecom sector. Journal Of Comparative Economics, 40, 22-43.

Bliss, C., \& Di Tella, R. (1997). Does competition kill corruption? Journal of Political Economy, 105, 1001-1023.

Boettke, P. J. (2001). Calculation and coordination: Essays on socialism and transitional political economy. London: Routledge.

Campos, N. F., \& Giovannoni, F. (2007). Lobbying, corruption and political influence. Public Choice, 131, 1-21.

Clarke, G., \& Xu, L. C. (2004). Privatization, competition, and corruption: How characteristics of bribe takers and payers affect bribes to utilities. Journal of Public Economics, 88, 2067-2097. 
Dusha, E. (2015). Intermediated corruption. International Economic Review, 56, 9971017. Duvanova, D. (2014). Economic regulations, red tape, and bureaucratic corruption in post-communist economies. World Development, 59, 298-312.

Hillman, A. L., \& Schnytzer, A. (1986). Illegal economic activities and purges in a Soviettype economy: A rent seeking perspective. International Review of Law and Economics, 6, 87-99.

Imam Prayogo and Teuku Afriza (2021), Perceptions of Educators, Accounting Students and Accountants Public Accountant against Ethics of Financial Statement Preparation (Studies at University and KAP in Semarang), Budapest International Research and Critics Institute-Journal (BIRCI-Journal), 1(4),189-101.

Leff, N. H. (1964). Economic development through bureaucratic corruption. American Behavioral Scientist, 8, 8-14.

Mauro, P. (1995),Corruption and growth. Quarterly Journal of Economics, 110, 681-712.

Miller, W. L. (2006), Corruption and corruptibility. World Development, 34, 371-380.

Model Ijah Mulyani Sihotang, and, Pipit Putri Hariani MD (2021), Implementation of Lesson Study Based Accounting Learning with Student Facilitator and Explaining Learning Model, Budapest International Research and Critics Institute-Journal (BIRCI-Journal), 1 ( 4).153-159 DOI: https://doi.org/10.33258/birci.v4i1.1558

Noah Echa Attah etal (2021), COVID 19 and Increased Security Challenges in Northern Nigeria: Interrogating Armed Banditry in Northwestern Nigeria, SIASAT Journal of Social, Cultural and Political Studies, 6 (1) 33- 44.

Papke, L., \& Wooldridge, J. M. (1996). Econometric methods for fractional response variables with an application to 401(K) plan participation rates. Journal of Applied Econometrics, 11, 619-632.

Ramalho, E. A., Ramalho, J., \& Murteira, J. (2009). Alternative estimating and testing empirical strategies for fractional regression models. Journal of Economic Surveys, $25,19-68$.

Reinikka, R., \& Svensson, J. (2006). Using micro-surveys to measure and explain corruption. World Development, 34, 359-370.

Rose-Ackerman, S. (1978). Corruption: A study in political economy. New York, NY: Academic Press.

Safavian, M. S., Graham, D. H., \& Gonzalez-Vega, C. (2001). Corruption and microenterprises in Russia. World Development, 29, 1215-1224.

Sequeira, S., \& Djankov, S. (2010). An empirical study of corruption in ports. Retrieved from http://ssrn.com/abstract=1589066.

Shleifer, A. (2004). Does competition destroy ethical behavior? American Economic Review, 94(2), 414-418.

Silva, J. M. C. S., \& Tenreyro, S. (2006). The log of gravity. Review of Economics and Statistics, 88, 641-658.

Straub, S. (2009). Regulatory intervention, corruption and competition. Review of Industrial Organization, 35, 123-148.

Svensson, J. (2005). Eight questions about corruption. Journal of Economic Perspectives, 19, 19-42. Treisman, D. (2000). The causes of corruption: A cross-national study. Journal of Public Economics, 76, 399-457.

Vachudova, M. (2009). Corruption and compliance in the EU's post-communist members and candidates. Journal of Common Market Studies., 47, 43-62.

Waluyo Jati(2021), The Effect of Non Performing Loan and Capital Adequacy Ratio on Return on Assets in Bank Victoria International, Tbk Period 2009-2018.Budapest 
International Research and Critics Institute-Journal (BIRCI-Journal) Volume 4, No 1,482-491, DOI: https://doi.org/10.33258/birci.v4i1.1630 